1 (2021), Juni 2021

E-ISSN: 2746-2471, DOI:

\title{
TREN BENTUK PART-TIME ENTREPRENEURSHIP UNTUK MENCAPAI KESUKSESAN
}

\author{
Dipa Teruna ${ }^{1}$, Tedy Ardiansyah ${ }^{2}$, \\ Fakultas Manajemen \\ ${ }^{1}$ Universitas Nasional, ${ }^{2}$ Universitas Indraprasta PGRI \\ dipateruna@gmail.com,tedy.ardiansyah@unindra.ac.id
}

Dikirim : 21 Juni 2021. Direvisi : 28 Juni 2021. Dipublikasikan : 30 Juni 2021

\begin{abstract}
ABSTRAK
Kegiatan wirausaha adalah kegiatan yang selaku menarik sepanjang waktu, namun kenyataannya bahwa orang yang melakukan kegiatan wirausaha adalah yang tidak mempunyai pekerjaaan atau penghasilan, namun kenyataannya ada juga seseorang yang memiliki pekerjaan tetap dan penghasilan ingin melakukan kegiatan wirausaha. Tujuan dari penelitian ini untuk mengetahui Part-Time Entrepreneurship (wirausahawan paruh waktu) mempunyai hubungan yang positif terhadap kegiatan wirausaha dan mempunyai efek yang baik kedepan sebagai wirausahawan yang sukses. Metode yang digunakan dengan menggunakan penelitian kualitatif dengan pendekatan deskriptif dimana data yang dikumpulkan dari hasil data sekunder berupa data literatur dari buku maupun jurnal. Hasil penelitian menunjukan bahwa wirausahawan paruh waktu mempunyai efek yang sangat signifikan untuk keberhasilan usaha dimana keberhasilan usaha tidak serta merta dapat di segala sektor usaha, sektor usaha yang tepat adalah pada bidang sektor jasa bisnis.
\end{abstract}

Kata Kunci: Paruh-waktu, Wirausaha, penghasilan, jasa bisnis

\section{A. PENDAHULUAN}

Perkembangan ekonomi global meningkat setiap tahun, peningkatan ini disebabkan oleh adanya inovasi, teknologi yang berkembang, serta peraturan pendukung dari pemerintah untuk mengawasi kegiatan perekonomian Indonesia(Permana, 2020). Tentu hal ini juga sangat berpengaruh pada kegiatan Kewirausahaan, dimana setiap wirausahwan harus mampu menghadapi hambatan dalam melakukan kegiatan usaha.

Kewirausahaan paruh waktu sebagai konteks dan pembelajaran kewirausahaan sebagai mekanisme melalui mana inovasi karyawan ditingkatkan. Kewirausahaan, sebagai sebuah proses menciptakan usaha untuk mengejar peluang nilai tambah (Bygrave \& Hofer, 1991), menawarkan wirausahawan konteks belajar yang unik. Memang, teori pembelajaran kewirausahaan menggambarkan pengembangan pengetahuan dan keterampilan unik melalui pengalaman kewirausahaan(Wang \& Chugh, 2014). Secara khusus, individu belajar untuk mengeksploitasi pengetahuan yang ada untuk secara bertahap meningkatkan produk dan layanan dan mengeksplorasi pengetahuan baru untuk menghasilkan ide-ide baru (politis, 2005). 


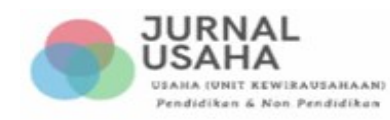

Vol 2, No. 1 (2021), Juni 2021

E-ISSN: 2746-2471, DOI:

Dengan demikian, pengusaha paruh waktu siap untuk mengembangkan kemampuan inovatif.Kewirausahaan paruh waktu mengacu pada partisipasi simultan dalam pekerjaan dan kewirausahaan di mana pekerja yang sudah bekerja terlibat dalam kegiatan Kewirausahaan (Folta et al., 2010). Sedangkan manajemen tradisional praktek mengerutkan kening pada karyawan yang memegang banyak pekerjaan (Jamal \& Crawford, 1981), menciptakan dan mengelola bisnis baru sambil memegang posisi pekerjaan utama mungkin menjadi kasus khusus dari beberapa pekerjaan mengingatkan bahwa seorang individu mengambil peran kewirausahaan baru daripada hanya peran karyawan tambahan (Stevenson \& Sahlman, 1987). Dalam hal ini, wirausahawan paruh waktu adalah pendiri dan pemilik dalam konteks pembelajaran yang unik (Dyer, 1994) yang dapat memfasilitasi pengembangan dan transfer kemampuan inovatif.

Sedikit penelitian tentang kewirausahaan paruh waktu mengasumsikan bahwa secara simultan keterlibatan peran kewirausahaan dan karyawan adalah tahap transisi menuju awal kewirausahaan penuh waktu. Namun penelitian lain menunjukkan bahwa awal kewirausahaan penuh waktu mungkin terjadi hanya setelah mencapai tingkat wirausaha yang tinggi hingga melewati pendapatan gaji (Folta et al., 2010a) atau ketika seorang individu bersedia dan mampu memberikan waktu yang cukup untuk hal baru bertualang (Burmeister et al., 2012). Baru-baru ini, riset mengusulkan bahwa dalam banyak kasus, pengusaha paruh waktu tidak pernah sepenuhnya bertransisi, malah memilih untuk tetap berada di keadaan antara wirausaha dan karir (Thorgren et al., 2016). Terlepas dari apakah kewirausahaan paruh waktu bersifat transisi atau permanen, ia menawarkan wirausahawan "potensi untuk belajar" yang mungkin tidak ada (Folta et al., 2010a). Kewirausahaan paruh waktu sebagai konteks "belajar sambil melakukan" (Petrova, 2010) dapat menghasilkan peningkatan keterampilan dan kemampuan kewirausahaan (Petrova, 2010; Raffiee \& Feng, 2014). Dengan demikian, individu terlibat dalam kewirausahaan, bahkan dalam kapasitas paruh waktu, berpartisipasi dalam pembelajaran kewirausahaan yang begitu penting. Dari latar belakang diatas maka peneliti tertarik untuk meneliti mengenai "Tren Bentuk Part-Time Entrepreneurship (Wirausaha Paruh Waktu) Untuk Mencapai Kesuksesan".

\section{B. KAJIAN PUSTAKA}

Memulai bisnis paruh waktu adalah gerbang populer untuk berwirausaha. Namun kemampuan setiap individu yang berbeda-beda merupakan peluang tidak terbatas bagi dirinya untuk menjadikan kemampuan tersebut menjadi sumber pendapatan (Theodora, 2020). Setiap wirausahawan wajib melakukan hal tersebut, namun yang unik saat sekarang adalah bilamana wirausaha di lakukan secara paruh waktu. Wirausahwan paruh waktu memiliki yang terbaik: Mereka dapat dengan mudah menjalankan bisnis untuk diri mereka sendiri tanpa mengorbankan gaji dan tunjangan yang tetap. Internet dan perangkat komunikasi seluler membuat pendirian dan menjalankan bisnis paruh waktu menjadi sangat mudah; banyak pengusaha paruh waktu menjalankan bisnis online dari kamar tidur di rumah mereka atau dari mana pun (Scarborough \& Cornwall, 2016). 


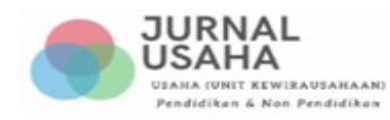

Vol 2, No. 1 (2021), Juni 2021

E-ISSN: 2746-2471, DOI:

Menurut Zwilling (2014) Banyak ahli akan memberitahu Anda bahwa Anda tidak dapat berhasil sebagai pengusaha paruh waktu, karena setiap startup yang baik akan membutuhkan komitmen 100 persen dari waktu dan energi Anda. Tetapi tidak banyak dari kita yang memiliki tabungan yang cukup untuk hidup selama satu tahun atau lebih tanpa gaji, mendanai startup, dan tetap memberi makan keluarga. Jadi saya sering merekomendasikan agar pengusaha mempertahankan pekerjaan mereka sampai startup menghasilkan pendapatan.

Tentu saja, jika Anda memiliki investor yang ingin memberi Anda uang, atau paman kaya untuk membuat Anda tetap bertahan, tidak ada yang salah dengan komitmen yang berdedikasi dan penuh untuk startup, dengan pencapaian yang lebih agresif dan ekspektasi pertumbuhan yang sepadan. Kita semua memahami risiko pesaing dengan cepat mendekat, dan faktor pasar berubah sebelum kita dapat meluncurkan solusi kita.

Bagi Anda yang memutuskan untuk mempertahankan pekerjaan harian Anda, berikut adalah beberapa rekomendasi pragmatis yang saya dukung tentang cara membuat kemajuan maksimal dalam startup Anda, sambil secara bersamaan menyulap peran penting keluarga dan pemberi kerja Anda yang lain. Faktanya, saran-saran ini memiliki nilai yang luar biasa, bahkan jika Anda berdedikasi dan berkomitmen penuh waktu untuk startup baru Anda:

1. Temukan co-founder yang dapat membuat Anda tetap seimbang.

Dua pendiri, keduanya bekerja paruh waktu, sebenarnya lebih baik daripada satu pendiri penuh waktu. Anda berdua membutuhkan keterampilan yang saling melengkapi, kemampuan untuk memperdebatkan alternatif dan kecenderungan untuk saling memotivasi, yang keduanya tidak dapat menandingi bekerja sendiri. Seseorang masih perlu menjadi pengambil keputusan akhir yang disepakati.

2. Jadwalkan waktu dan hari tetap untuk startup, bekerja dengan tim.

Membangun startup adalah kerja keras, dan membutuhkan disiplin untuk menyelesaikannya. Bekerja paruh waktu tidak berarti bekerja secara acak sendirian. Berkomitmen pada waktu akhir pekan reguler dan beberapa malam tertentu per minggu di mana Anda bertemu dengan tim dan fokus hanya pada startup.

3. Lebih baik dalam mengatakan "tidak" kepada teman-teman Anda

Belajar mengatur waktu Anda sendiri sangat penting. Semua orang di sekitar Anda senang menambahkan sesuatu ke jadwal Anda, dan mengurangi daftar tugas mereka. Kuncinya adalah belajar mengatakan tidak tanpa menawarkan daftar panjang alasan, atau mengeluh tentang betapa sibuknya Anda. Tidak pernah mungkin untuk memuaskan semua orang, jadi pertama-tama jujurlah pada prioritas Anda sendiri.

4. Tetapkan tonggak yang realistis dan anggap serius.

Sangat mudah bagi pekerja paruh waktu untuk membuat alasan bahwa prioritas lain menyebabkan Anda melewatkan pencapaian, tetapi hasil dan metrik yang dapat diprediksi dalam mode ini bahkan lebih penting daripada untuk anggota penuh waktu. Gunakan aturan 80/20 untuk memaksimalkan produktivitas dapatkan hasil 80 persen dari 20 persen upaya terfokus. 


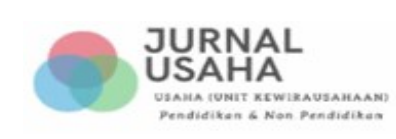

Vol 2, No. 1 (2021), Juni 2021

E-ISSN: 2746-2471, DOI:

5. Pilih ide bisnis yang memiliki landasan lebih panjang.

Beberapa ide startup bergantung pada tren yang muncul dengan cepat, atau memiliki banyak pesaing yang berjuang untuk pasar yang terbatas. Anda tidak dapat bergerak cukup cepat secara paruh waktu untuk menang di area ini. Di sisi lain, jika Anda memiliki teknologi baru, dengan paten yang diajukan, Anda mungkin memiliki lebih banyak waktu untuk memperbaikinya.

6. Persiapkan diri Anda untuk perjalanan sukses yang lebih panjang.

Seth Godin terkenal karena mengatakan bahwa waktu rata-rata untuk sukses dalam semalam dalam sebuah startup adalah enam tahun, bahkan bekerja penuh waktu. Seperti solusi startup lainnya, versi pertama kemungkinan akan salah, dan memerlukan satu atau lebih pivot. Belajarlah untuk mencari indikasi kecil keberhasilan untuk membuat Anda tetap termotivasi.

7. Jadikan belajar sebagai panggilan penuh waktu Anda.

Tidak peduli berapa banyak komitmen penuh waktu, paruh waktu, dan keluarga yang Anda miliki, Anda selalu perlu mengukir waktu untuk mempelajari hal-hal baru. Belajar tidak mencuri dari majikan mana pun, dan itu mempersiapkan Anda untuk semua masa depan Anda. Jangan menunggu siapa pun membayar Anda ke kelas, atau memberi Anda waktu istirahat untuk pelatihan. Itu tidak akan terjadi.

Keuntungan berhenti dari pekerjaan harian Anda lebih awal adalah menghilangkan semua alasan, dan semua keraguan dari Anda dan orang lain, bahwa startup baru hanyalah hobi. Tidak ada yang mendorong seorang wirausahawan seperti lapar, bergantung pada hasil, dan melihat utang yang menumpuk. Tanpa disiplin diri, banyak calon pengusaha menemukan bahwa satu fokus adalah satu-satunya cara untuk menyelesaikan sesuatu.

Beberapa contoh pekerjaan paruh-waktu secara umum yang ada di Indonesia dan paling digemari antara lain (Omblogging, 2019):

1. Bisnis Pulsa Elektrik

Bisnis paling fleksibel yang mudah dilakukan tanpa menyita waktu adalah bisnis pulsa elektrik. Bisnis ini sangat cocok dijalankan oleh karyawan yang merasa gaji belum mencukupi.

Tidak perlu jenjang pendidikan yang tinggi, asal anda bisa mengoperasikan telpon genggam maka anda sudah bisa menjalankan bisnis ini. Bahkan saat ini sudah ada sistem pengisian pulsa yang hanya menggunakan website.

Walau fleksibel dan mudah dilakukan, bisnis ini tidak pernah kehabisan potensi. Saat ini pulsa sudah merupakan kebutuhan primer semua orang, apalagi dengan meningkatnya jumlah pengguna ponsel dari waktu ke waktu.

Apabila anda tertarik ingin menjadi agen penjualan pulsa dan kuota, anda bisa mencoba beberapa layanan yang menyediakan jasa jual pulsa.

Saat ini ada banyak yang menyediakan harga murah, tapi anda harus pastikan bahwa anda dilayani secara akurat,degan itu anda akan mendapat bimbingan. Bisa langsung dari owner dan bisa juga melalui group line atau forum chat yang mereka sediakan.

2. Bisnis Menjual Online 


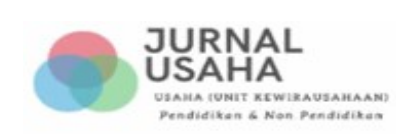

Vol 2, No. 1 (2021), Juni 2021

E-ISSN: 2746-2471, DOI:

Dengan kemajuan teknologi saat ini, sangat mudah untuk menjalankan bisnis jualan online. Hal ini sangat cocok bagi anda yang mempunyai bakat dagang. Bahkan sudah banyak kasus dimana menjual secara online menghasilkan lebih banyak daripada menjual secara langsung.

Sangat banyak kemudahan dalam menjalankan bisnis ini. Anda bisa menjual di marketplace, sosial media ataupun membuat toko online sendiri.

Bahkan anda tidak perlu memliki produk untuk bisa berjualan online. Loh kok bisa? Yah saat ini sedang gencar-gencarnya sistem dropshipping dimana anda hanya menjual produk orang lain dan bisa mematok keuntungan per pieces.

Tapi timbul masalah karena banyak reseller yang ikut melakukan sistem dropshipping sehingga jadi sulit untuk menemukan produsen utama.

Jika anda berniat memulai bisnis online coba pahami Tips cerdas promosi bisnis online. Pastikan pula anda sudah dibekali ilmu yang mumpuni, untuk itu pelajari Cara Memilih Bisnis Online Tanpa Modal Yang Tepat.

Sebenarnya selain bisnis online saya juga ingin mengenalkan anda 4 Macam Peluang Usaha Yang Kurang Pesaing Cocok Untuk Semua Kalangan.

Jika anda ingin memulai bisnis menjual online, maka menemukan produsen utama merupakan hal wajib. Memperoleh barang langsung dari produsen utama membuat harga barang menjadi murah sehingga anda bisa mematok keuntungan yang banyak tapi tetap bersaing di pasaran.

Ada beberapa perusahaan yang menyediakan data pin konveksi yang bisa anda coba. Pin konveksi merupakan kumpulan contact person para produsen utama, bisa berupa pin bbm ataupun id line.

Anda bisa invite mereka melalui contact yang disediakan. Cari yang siap kerjasama dengan Anda, pastikan anda akan dibimbing full dari awal sampai akhir dalam membangun usaha jualan online anda.

3. Bisnis Agen Properti

Menjadi agen properti sangat layak dicoba bagi anda yang ingin mempunyai keuntungan banyak dalam sekali transaksi. Konon fee yang ditawarkan bisa mencapai $5 \%$ dari harga properti. Ini tentu lebih banyak dari bisnis-bisnis yang lain semisal agen pulsa atau jual online.

Hanya saja untuk menjual 1 properti pun, akan sulit terjadi jika anda adalah seorang pemula. Sebelumnya anda harus membangun self image yang baik sehingga calon pembeli memberikan kepercayaan kepada anda.

4. Bisnis Cafe

Saat ini bisnis café sangat membludak di mana-mana. Tentunya karena bisnis ini menawarkan hasil yang menggiurkan dengan mudah. Anda hanya perlu membuat resep makanan atau minuman unik, menyewa tempat strategis, serta mempekerjakan beberapa karyawan. Anda bahkan tidak perlu untuk setiap hari mengecek kondisi café anda.

Jangan takut café anda akan sepi. Sekarang setiap orang berusaha untuk mendapatkan lokasi berdiam diri untuk mendapatkan internet yang cepat yaitu aksesnya.Pastikan saja cafe anda rapih dan bersih maka pengujung akan terus berdatangan.

5. Menjadi Blogger 


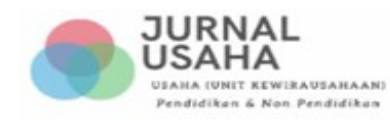

Vol 2, No. 1 (2021), Juni 2021

E-ISSN: 2746-2471, DOI:

Bila menyenangi menulis terutama pada waktu-waktu yang kosong untuk itu blogger merupakan bagian dari suatu impian dan tentunya bijak dalam memilih blogger. Menjadi blogger bisa dilakukan secara full time maupun part time. Jangan salah, blogger part time pun bisa menghasilkan earning yang lebih banyak dari blogger full time.

Konten merupakan bagian pokok sebagai blogger, semakin konten menarik tentunya lebih di keluarkan usaha kreatif yang amat tinggi.

Penghasilan seorang blogger diperoleh dari iklan yang dipasang di blog. Walau terdengar sepele, blogger yang bisa menghasilkan ratusan juta.

6. Menjadi Youtuber

Menjadi youtuber sama saja dengan blogger. Penghasilan utama berasal dari iklan yang dipasang di channel mereka dan sudah banyak yang sukses dari pekerjaan ini. Hanya saja konten yang dibuat berupa video yang di share di platform youtube.

\section{METODE PENELITIAN}

Penelitian ini merupakan studi literatur dalam penelitian kualitatif tentang pentingnya wirausahawan parah waktu. Metodologi adalah suatu proses, prinsip, atau prosedur yang digunakan untuk mengatasi suatu masalah dan menemukan jawabannya. Dengan kata lain, metodologi adalah pendekatan umum untuk mengeksplorasi topik penelitian (Deddy mulyana, 2004). Jenis survei yang digunakan adalah pendekatan kualitatif. Artinya, penelitian yang digunakan untuk menyelidiki keadaan objek alam, alat utama bagi peneliti, metode pengumpulan data dilakukan secara kualitatif, analisis data bersifat induktif/kualitatif, dan ditekankan pada hasil. Kualitatif daripada digeneralisasi (Sugiyono, 2017).

\section{HASIL}

Beberapa dari hasil penelitan memberikan variasi dari hasil kegiatan wirausaha paruh waktu dimana dinyatkan dengan beberapa penelitian dibawah:

Temuan kunci dari penelitian ini menekankan bahwa pengusaha paruh waktu dengan kemampuan alokasi sumber daya yang lebih tinggi lebih mungkin untuk berubah menjadi pengusaha penuh waktu, dan kemampuan mengenali peluang tidak diverifikasi oleh asumsi ini. Selain itu, sumber daya kewirausahaan secara positif mengatur hubungan antara dua jenis kemampuan kewirausahaan dan niat transformasi (Sun, Huang, Su, \& Yang, 2020).

Penelitian sebelumnya telah memilih individu seperti biasa antara pekerjaan berupah dan kewirausahaan. Penelitian ini menyoroti Pentingnya sikap mempertimbangkan kewirausahaan gabungan antara full dan paruh waktu sebagai proses yang berbeda dari awal kewirausahaan yang memungkinkan pembelajaran dan mungkin sangat berguna untuk individu yang pintar namun tidak memiliki pengalaman Kewirausahaan (Folta et al., 2010).

Hipotesis bahwa kewirausahaan paruh waktu memberikan kesempatan bagi individu untuk memperoleh pengetahuan dan keterampilan yang kondusif untuk melakukan inovasi perilaku sebagai karyawan. Analisis regresi bertingkat 


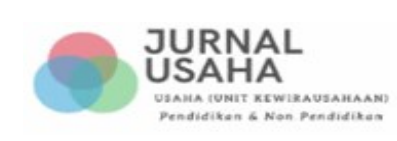

Vol 2, No. 1 (2021), Juni 2021

E-ISSN: 2746-2471, DOI:

dari sampel 1.221 tanggapan karyawan di 137 unit organisasi memberikan bukti untuk mendukung hipotesis transfer positif (Marshall et al., 2018).

Untuk menjelaskan kewirausahaan paruh waktu, mengembangkan model di mana individu menjadi paruh waktu wirausahawan karena mereka tidak mengetahui kemampuan wirausaha mereka sebelumnya. Awalnya, mereka akan lebih suka menghabiskan hanya sebagian kecil waktu dalam berwirausaha tanpa risiko kelaparan jika kemampuan mereka berubah keluar menjadi rendah. Berdasarkan harapan mereka, pengusaha memilih berapa banyak waktu yang dihabiskan dalam bisnis dan berapa modal yang harus diinvestasikan. Setelah menghabiskan sejumlah waktu sebagai pengusaha paruh waktu, individu harus membuat pilihan antara mengembangkan bisnis yang sukses sebagai wirausahawan penuh waktu dan kembali penuh waktu ke pekerjaan luar yang dibayar. Ketika informasi tentang kemampuan tidak cukup untuk membuat pilihan, pengusaha akan melanjutkan sebagai paruh waktu untuk setidaknya satu periode lagi. Jika pengusaha memiliki kemampuan sejati rendah, kemungkinan bukti akan merugikan dan pengusaha akan mengurangi waktunya dalam bisnis dan menarik segera. Jika buktinya menguntungkan, individu akan meningkatkan waktu yang dihabiskan di bisnis dan akan segera beralih ke kewirausahaan penuh waktu. Model tersebut memunculkan seleksi industri, memprediksi bahwa lebih banyak pengusaha paruh waktu akan diamati di sektor-sektor di mana kemampuan tidak diketahui sebelumnya waktu. Membandingkan implikasi model dengan bukti empiris menggunakan PSED. jumlah pengusaha paruh waktu di PSED sangat tinggi di sektor-sektor seperti jasa bisnis. Hal sebaliknya berlaku untuk pertanian, konstruksi dan transportasi (Petrova, 2011).

\section{E. SIMPULAN}

Hipotesis untuk menjawab wirausaha paruh waktu mempunyai beberapa hasil dimana antara lain adalah: bahwa wirausaha paruh waktu sangat positif untuk dijalankan terutama bagi mereka yang mempunyai pekerjaan tetap ataupun mempunyai penghasilan yang mencukupi.

Pengusaha paruh waktu bila sudah mempunyai sumber daya yang mencukupi akan mengubah menjadi pengusaha penuh waktu hal ini dipengaruhi juga oleh kemampuan wirausaha dan niat melakukan transformasi dalam berwirausaha

Bahwa wirausaha paruh waktu adalah individu yang pintar namun tidak memiliki pengalaman dalam berwirausaha.

Pengusaha paruh waktu adalah seorang individu yang memiliki pengetahuan, keterampilan yang kondusi serta inovasi perilaku dalam melakukan suatu kegiatan positif.

Pengusaha paruh waktu lebih condong kearah sektor seperti jasa bisnis dibandingkan pertanian, konstruksi dan transportasi. 


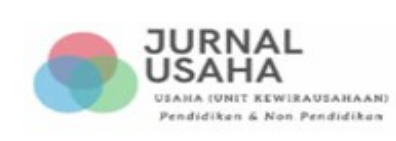

Vol 2, No. 1 (2021), Juni 2021

E-ISSN: 2746-2471, DOI:

\section{DAFTAR PUSTAKA}

Ardiansyah, T. (2020). Model Platform e-Commercce dalam mendukung kesuksesan UMKM di Indonesia. Jurnal Usaha, 1(1).

Burmeister, Levesque, \& Schade. (2012). Are entrepreneurs influenced by risk attitude, regulatory focus or both? An experiment on entrepreneurs' time allocation. Journal of Business Venturing, 27, 456-476.

Bygrave, W. D., \& Hofer, C. W. (1991). Theorizing about entrepreneurship. Entrepreneurship Theory and Practice.

Deddy mulyana. (2004). Metodologi Penelitian Kualitatif (Paradigma Baru Ilmu Komunikasi Dan Imu Sosial lainnya). Bandung: PT Remaja Rosmadakarya,.

Dyer. (1994). Toward a theory of entrepreneurial careers. Entrepreneurship Theory and Practice.

Folta, Delmar, \& Wennberg. (2010a). Hybrid entrepreneurship. Management Science.

Folta, T. B., Delmar, F., \& Wennberg, K. (2010b). Hybrid Entrepreneurship. Informs JSTOR, 56(2), 253-269.

Jamal, \& Crawford. (1981). Consequences of extended work hours: A comparison of moonlighters, overtim_ers, and modal employees. Human Resource Management.

Marshall, D. R., Davis, W. D., Dibrell, C., \& Ammeter, A. P. (2018). Learning off the Job: Examining Part-time Entrepreneurs as Innovative Employees. Journal of Management, 20(10), 1-20.

Omblogging. (2019). Contoh Bisnis Usaha Paruh Waktu Yang Bisa Anda Coba. Retrieved from https://www.omblogging.com/contoh-bisnis-usaha-paruhwaktu-yang-bisa-anda-coba/

Permana, I. (2020). Kinerja Usaha Bumdes Di Kabupaten Bekasi Dipengaruhi Oleh Orientasi Kewirausahaan, Teknologi Digital Kewirausahaan Dan Motivasi Usaha. Jurnal Usaha, 1(2).

Petrova. (2010). Part-time entrepreneurship, learning and ability. Journal of Management Policy and Practice, (12), 64-75.

Petrova, K. (2011). Part-Time Entrepreneurship, Learning and Ability. Management Policy and Practice, 12(1), 64.

politis. (2005). The process of entrepreneurial learning: A conceptual framework. Entrepreneurship Theory and Practice.

Raffiee, \& Feng. (2014). Should I quit my day job? A hybrid path to entrepreneurship. Academy of Management Journal, (57), 936-963.

Scarborough, N. M., \& Cornwall, J. R. (2016). Essentials of Entrepreneurship and Small Business Management (8th ed.). Harlow: Pearson Education Limited.

Stevenson, \& Sahlman. (1987). Entrepreneurship: A process, not a person. Cambridge, MA: Harvard Business School.

Sugiyono, P. D. (2017). Metode Penelitian Kualitatif. bandung: alfabeta.

Sun, J., Huang, Y., Su, D., \& Yang, C. (2020). Data mining and analysis of parttime entrepreneurs from the perspective of entrepreneurial ability. 
Vol 2, No. 1 (2021), Juni 2021

E-ISSN: 2746-2471, DOI:

Information Systems and E-Business Management, 18, 455-484.

Theodora, B. D. (2020). Perbedaan Motivasi Internal Dan Eksternal Terhadap Minat Teknopreneur Mahasiswa Informatika. Jurnal Usaha, 1(1).

Thorgren, Nordstorm, \& Wincent. (2016). Hybrid entrepreneurs' second-step choice: The nonlin_ear relationship between age and intention to enter fulltime entrepreneurship. Journal of Business Venturing Insights, (5), 14-18.

Wang, \& Chugh. (2014). Entrepreneurial learning: Past research and future challenges. International Journal of Management Reviews, (16), 24-61.

Zwilling, M. (2014). 7 Musts to Make Part-Time Entrepreneurship Work for You. Retrieved from https://www.entrepreneur.com/article/238169 